\title{
酸素原料オゾナイザの電極表面の錆がオゾン発生に及ぼす影響
}

$\begin{array}{rrrrrc}\text { 正 員 } & \text { 田中 } & \text { 正明* } & \text { 非会員 小川 } & \text { 周治** } \\ \text { 正 員 和田 } & \text { 昇 } & \text { 正 員 } & \text { 吉安 } & \text { 一* } \\ \text { 正 員 八木 } & \text { 重典 } & & & & \end{array}$

\section{Influence of Rust on Electrodes of Oxygen-fed Ozonizer to Ozone Generation}

Masaaki Tanaka*, Member, Shuji Ogawa**, Non-member, Noboru Wada*, Member,

Hajimu Yoshiyasu*, Member, Shigenori Yagi* , Member

The rust is generated on a metal electrode when the oxygen-fed ozonizer with a short gap is driven in a high discharge density. The ozonizer consists of a metal electrode and glass one, and the rust on a metal electrode disperses to a glass electrode. We found that the ozone yield efficiency improves about $20 \%$ in some condition when the rust adheres on the glass electrode. The rust is the oxidized chemical compounds of $\mathrm{Fe}, \mathrm{Ni}, \mathrm{Cr}, \mathrm{Mo}$ which are a materials of a metal electrode(SUS304). We examined the characteristics of ozone generation using the glass electrode painting various kinds of the oxidized chemical compounds including above materials. As a result, the same characteristic in case of generation of rust is obtained when $\mathrm{CrO}_{3}$ is painted. We conclude that the change of characteristics is caused by the $\mathrm{Cr}$ in the rust.

キーワード : オゾン, オゾナイザ, 無声放電, 電極, 錆, 酸素原料

Keywords : ozone, ozonizer, silent discharge, electrode, rust, oxygen-fed

\section{1. まえがき}

酸素原料の無声放電式オゾナイザのオゾン発生特性やそ の生成機構については，著者らは既に幾つか報告している が(1)(2)，これらの実験の過程で興味ある現象を見いだしてい た。それは実験の前に放電電極の表面を清浄にしておくと, 放電の時間経過とともに金属電極の放電面に錆が析出して ゆき, これに伴いオゾン収率が変化し, やがて一定の值に 落ち着くと言う現象である。酸素原料オゾナイザでは電極 から錆が析出すると，清浄な場合に比べて条件によっては オン゙ン収率が $20 \%$ 近くも向上する。従来では一般的にはオ ゾナイザの電極は清浄なものが良いとされてきたが，この 現象はその逆をゆくものであり，オゾン生成機構の究明の 見地からだけでなく，実用的な面からも興味深い現象であ る。

ところで，この様な現象は従来良く研究されていたオゾ

\footnotetext{
* 三菱電機(株) 先端技術総合研究所

干661-8661 尼崎市塚口本町 8-1-1

Advanced Technology R\&D Center, Mitsubishi Electric Corporation

8-1-1, Tsukaguchi-Honmachi, Amagasaki, 661-8661

** 三菱電機(株) 中部支社

于450-8552 名古屋市中村区名駅 3-28-12

Chubu Branch office, Mitsubishi Electric Corporation

3-28-12, Meieki, Nakamura-ku, Nagoya, 450-8552
}

ナイザの放電条件の放電ギャップ長が $2 \sim 3 \mathrm{~mm}$ 程度, かつ 放電密度（単位電極面積あたりの放電電力） $0.2 \mathrm{watt} / \mathrm{cm}^{2}$ 前 後では明確には見られない。著者らが研究の対象にしてい るのはオゾナイザの大容量・コンパクト化を目指したもの で, 従来のものに比べて, 放電ギャップ長は半分以下, 放 電密度が一桁近く高いオゾナイザであり, かつ酸素原料で あるためにこの現象が顕著に現れたものである。

電極表面状態とオゾン発生に関しては化合物を電極に添 付してオゾン発生を調べた報告はあるが(3)(4), 電極表面に析 出する錆とオゾン収率の関係を体系的に調べた報告は見あ たらない。最近では空気原料に代わり酸素原料オゾナイザ が多く使われるようになり，また短ギャップ化してきてい る(5)(6)。従って, この現象を詳細に調べてその原因を究明す ることは, オン゙ン発生特性の実験方法の知見を提供すると 言う実用的な観点からも意義深い。

本論文は, 電極表面の錆とオゾン収率の変化を広範囲の 条件で実験的に調べてその現象と原因を明らかにし, また 実用的な観点からオゾン収率が向上するオゾナイザの動作 条件についても示している。

\section{2. 実 験}

図 1 は実験に使用した両電極冷却型円筒のオゾナイザの 
小型実験モデルである。ガラス電極は外径が $51.2 \mathrm{~mm}$, 放 電有効長 $100 \mathrm{~mm}$ のホウケイ酸ガラスで, 金属電極は不錆鋼 （材質； SUS304）である。両電極とも温度 $\mathrm{T}_{\mathrm{w}}=0^{\circ} \mathrm{C}$ の $20 \%$ のエチレングリコール水溶液により水冷されている。冷却 水はイオン交換樹脂により抵抗率が $5 \mathrm{M} \Omega \cdot \mathrm{cm}$ 以上に保た れている。放電ギャップ長 $\mathrm{d}$ はガラス電極の外径を一定と し, 金属電極の内径を変化させて $\mathrm{d}=0.5,1.2,1.9,2.6 \mathrm{~mm}$ の 4 通りに変化させた。

本文中で清浄な電極と称しているのは，ガラス電極の場 合，表面を王水（塩酸と硝酸の混合液）で洗浄し，また金 属電極の場合は酸化ニッケルの微粉末で研磨し, その後に 蒸留水で十分に洗浄したものである。

実験のフローを図 2 に示す。原料酸素は純度 $99.6 \%$ の市 販の酸素ボンベを用いて吸着式ガス乾燥機で露点を $-60^{\circ} \mathrm{C}$ して使用した。実験を通じてオゾナイザでの原料ガスの圧 力 $\mathrm{P}$ は大気圧 $(0.1 \mathrm{MPa})$ 一定である。

オゾン濃度は KI滴定法で校正した紫外線吸収式オゾンモ ニターで測定した。電源は周波数が $0.65 \sim 3 \mathrm{k} \mathrm{Hz}$ の正弦波 を発生するインバータを使用し，オゾナイザに投入する放 電電力の制御は周波数と電圧を変化させて行った。放電電 力は電圧 $\mathrm{V}$ と電荷（電流積分） Q の VQ リサジュー図形の 面積から求めた。

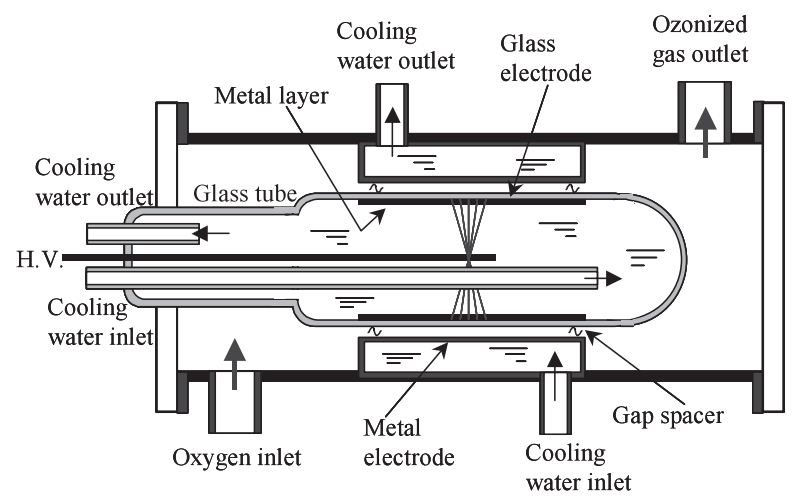

困 1 オゾナイザの構造

Fig. 1. Structure of ozonizer.

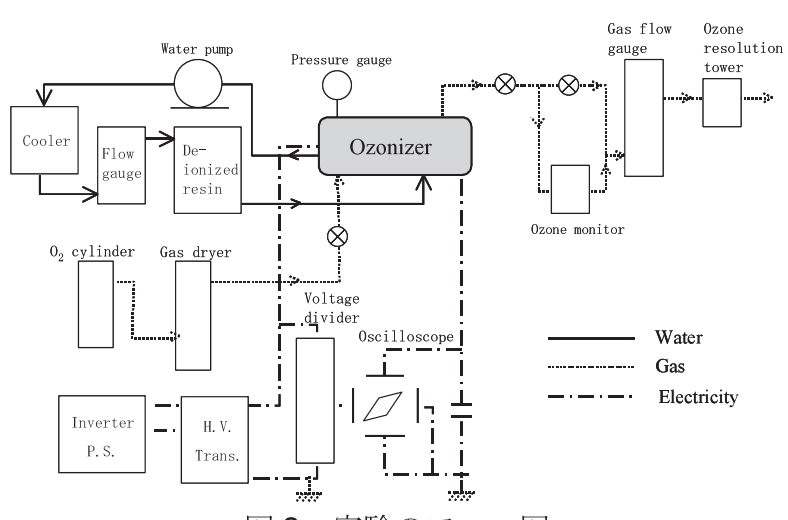

図 2 実験のフロー図

Fig. 2. Flow diagram of experiment.

\section{3. 実験結果と検討}

〈3-1〉 オゾン発生特性の変化酸素を原料気体とし て清浄な電極のオゾナイザを放電させていると, 放電電力 $\mathrm{W}$ が一定でもオゾン発生量 $\mathrm{Y}_{\mathrm{O} 3}$ が変化してゆき, やがて一 定の值に落ち着く。この変化は放電ギャップ長 $\mathrm{d}$ が小さいほ ぞ, また放電密度 W/S（S は電極面積）が大きいほど早い。 例えば W/S $=2 \mathrm{watt} / \mathrm{cm}^{2}$ で $\mathrm{d}=2.6 \mathrm{~mm}$ の条件では約 40 時間 放電させてもオゾン発生特性の変化は見られなかったが, $\mathrm{d}=0.5 \mathrm{~mm}$ では数十分でオゾン発生量の変化が明確に検知 でき, 10〜15 時間でその変化は落ち着き一定の特性になる。

図 3 に一例として $\mathrm{d}=1.2 \mathrm{~mm}$ のオゾナイザについて清浄 な場合（破線で示すグラフ）と, 約 30 時間放電させてオゾ ン発生量の変化が無くなった場合（実線で示すグラフ）の オン゙ン発生特性を比較したものを示す。眓より, 両者の才 ゾン発生特性は相当に異なっており, $20 \%$ 近くオゾン発生量 が向上している条件もある事が分かる。

ところで，この様にオゾン発生量が変化したときには， 電極には必ず褐色の錆が発生していることを実験を通じて 見いだしている。錆はギャップ長 $\mathrm{d}$ が小さいほど, また放 電密度 W/S が大きいほど速やかに現れ, 前述のオゾン発生 の変化の早さに対応している。 $\mathrm{d}=2.6 \mathrm{~mm}$ では約 40 時間放 電を行わせても目視的には錆は全く発生しなかった。

また金属電極の材質を腐食耐性の強い不錆鋼 SUS306, SUS316 で製作して同様の実験を行ったが，錆の発生状況

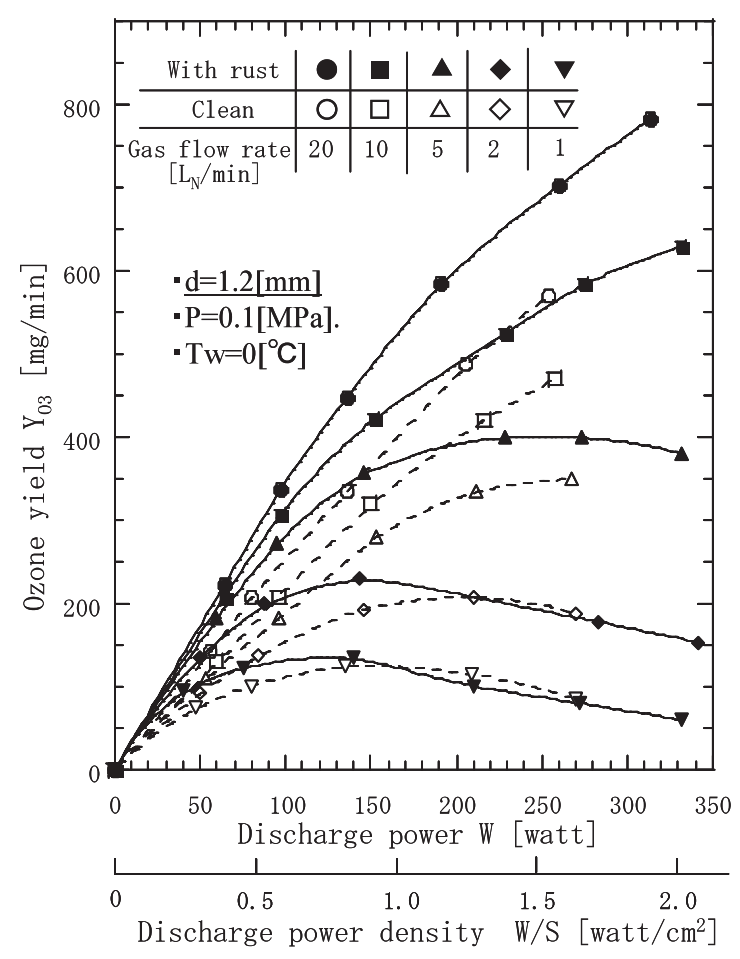

図 3 電極が清浄な場合と錆が付着した場合の オゾン発生特性の比較

Fig. 3. Comparison of ozone generation in clean electrode and electrode with rust. 
は SUS304 の材質の場合と全く同様であった。錆は放電面 以外には発生していなく, オゾンや酸素による腐食とは異 なる。後に示すが錆の褐色の成分は不錆鋼の成分の酸化物 である。

放電に暴露する電極面では電子やイオンが衝突してい る。これらの粒子のエネルギーはギャップ長が短いほど大 きいので(7), 放電ギャップが短いほど不錆鋼表面の不動態膜 が破壊されやすく, 且つ酸素原子やオゾンなどの酸化力の 強いガスが存在しているため不錆鋼の金属電極の放電面に のみに錆が発生するものと考えられる。

錆は褐色の微粉末状（ココアパウダー状）のもので，後 に明らかにする様に金属電極（SUS304）から発生したもの であるが錆は飛散して，これに対向して設置されているガ ラス電極にも付着しており, ガラス電極は淡い褐色を呈し ている。錆はガラス表面が透けて見える程度の付着である。 付着の様子は実験機による数百時間のオーダの実験や, 製 品として納入し数年運転したオゾナイザの電極でも，目視 的には大差はなく錆が厚く堆積してゆく事は無い。これは 錆がある程度金属電極を覆うと, 錆自体が保護皮膜のよう に働き，放電が金属電極に直接暴露しなくなり，錆はそれ 以上発生・進展しないからと推察される。

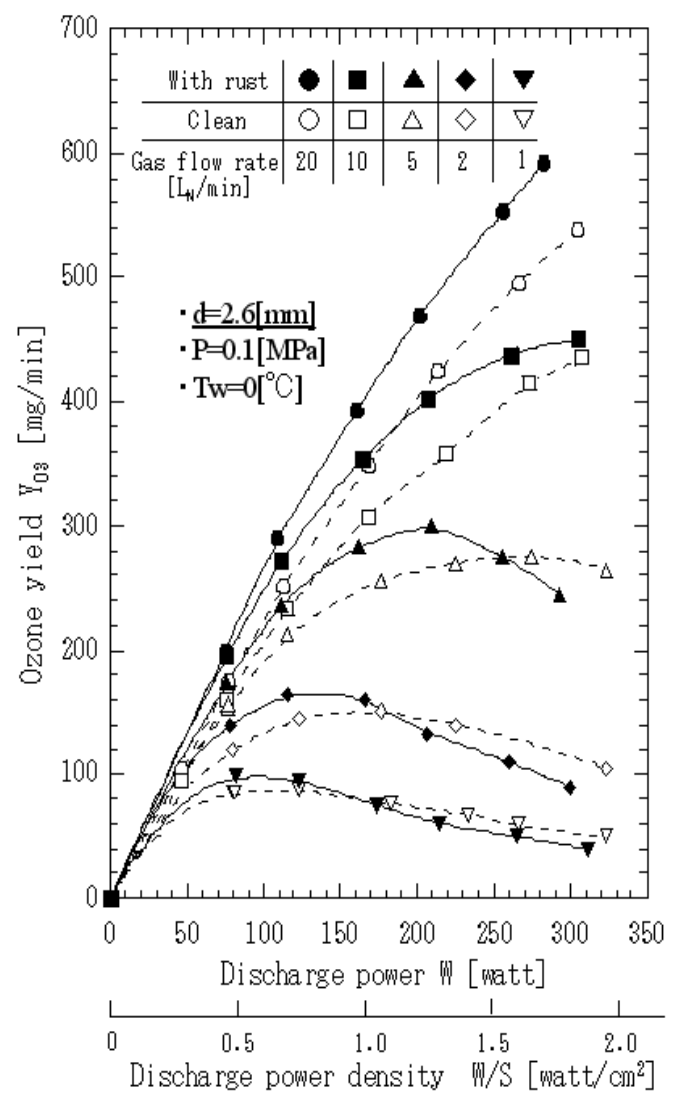

図 4 錆付着のガラス電極を清浄な金属電極に 挿入した場合のオゾン発生特性

Fig. 4. Characteristics of ozone generation when glass electrode with rust is inserted in ozonizer.
次に錆がオゾン発生に影響を与えていることを確認し， さらにガラス電極, 金属電極のいずれの電極に付着する錆 がオゾン発生に影響を与えているのかを調べるために, 図 3 の実線で示す特性が得られたオゾナイザ，すなわちガラス 及び金属電極の両方に錆が付着した状態のオゾナイザを使 って次のような実験を行った。

（i ）ガラスおよび金属電極の両方を清浄にする。

（ii） ガラス電極のみ清浄にする（金属電極には錆が付 着したまま)。

（iii）金属電極の夕清浄にする（ガラス電極には錆が付 着したまま)。

上の様な操作の後, オゾン発生特性を調べると, （ｉ）, （ii）は図 3 の破線で示す清浄な電極の特性と一致し，（iii） は図 3 の実線で示す両電極に錆が付着した特性と一致する 結果が得られた。

さらに次のような実験も行った。 $\mathrm{d}=2.6 \mathrm{~mm}$ のオゾナイ ザの場合には, 前述したように 40 時間放電させても錆は発 生せず，オゾン発生特性も変化しない。そこで図 3 の実線 で示すオゾン発生特性が得られたオゾナイザのガラス電極( 錆が付着）を抜きとって，ギャップ長 $\mathrm{d}=2.6 \mathrm{~mm}$ に対応す る清浄な状態の金属電極に挿入し, オゾン発生特性を調べ た。その結果を図 4 に示すが $\mathrm{d}=2.6 \mathrm{~mm}$ の清浄な電極の場 合のオゾン発生特性とは異なった特性が得られた。このこ とからもガラス電極に付着する錆がオゾン発生に影響を与 えていることが確認された。尚, 放電は 10 時間程度行わせ ているが図 4 の実線で示寸オゾン発生特性は安定していた。

以上の実験結果から, オゾン発生の変化は電極から析出 する錆に起因している事が確認され，さらに金属電極上の 錆は無関係で，ガラス電極に付着する錆がその原因である ことが明確になった。

〈3.2〉放電の状態の変化 例えば図 3 , 図 4 グラフで ガス流量 $\mathrm{Q}$ が大きく, 且つ放電電力 $\mathrm{W}$ がゼロに近づくとき （オゾン濃度が低い領域）のグラフの傾きは最大オゾン収 率 $\eta \max$ を表す(8)。図 5 はギャップ長 $\mathrm{d}$ と $\eta \max$ の関係を実験 から求めたものである。ただし前述したように $\mathrm{d}=0.5 \mathrm{~mm}$ では錆の析出速度が早く, 実験中にオゾン発生が変化する ため, $\mathrm{d}=0.5 \mathrm{~mm}$ の清浄な状態のデータは収得できない。

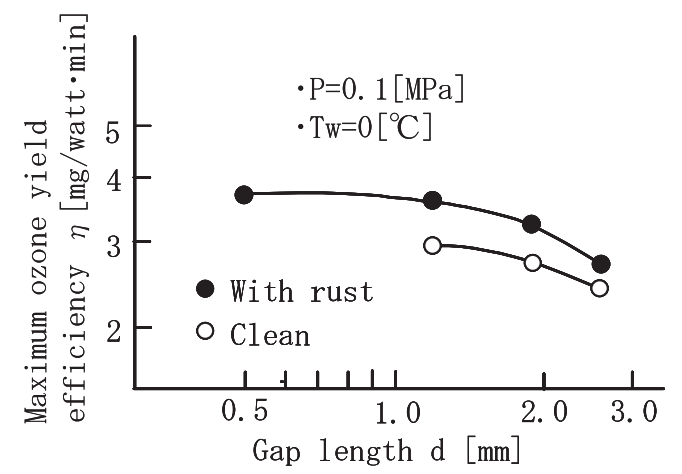

図 5 最大オゾン収率

Fig. 5. Maximum ozone yield efficiency. 


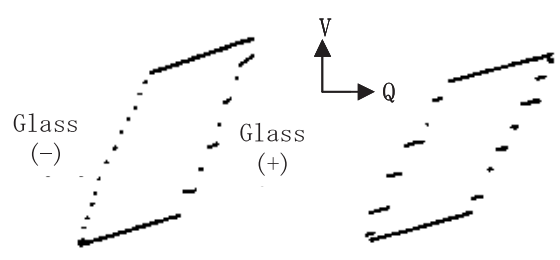

$\begin{array}{ll}\text { (a) Clean } & \text { (b) With rust }\end{array}$

図 6 リサジュー図形

Fig. 6. Lisaajous` figure.

図 5 から， $\eta$ max.は錆が付着した方が常に大きくなっている。 良く知られているように，オゾン濃度の小さい領域での才 ゾン収率，即ち最大オゾン収率 $\eta$ max. は放電空間の温度には 無関係であり，“放電” の状態 “によってのみ決まる(2)(8)。 よって電極に錆が付着すると $\eta$ max.が向上するのは放電の 状態が変化していることを表している。

またこの他に，錆が付着すると電圧 $\mathrm{V}$ と電荷 $\mathrm{Q}$ （電流積 分）の VQ リサジュー図形の放電期間に相当する部分の動 摇（ギザギザ）の大きさが図 6 の様に変化する現象が観測 される。図より放電期間に相当するリサジュー図形の動摇 の様子は，金属電極がマイナスの極性（ガラスがプラス） のときは電極が清浄, 錆付着の場合とも大きな変化は無い が，ガラス電極がマイナスの極性の場合には，錆が付着す ると動摇は大きくなっており，ガラス電極からの電子放出 に変化が生じていることを示唆している。これは金属電極 の錆は無関係でガラス電極に錆が付着するとオゾン発生が 変化すると言う現象と対応している。

以上，錆が付着すると何らかの放電の変化が起こってい ることを表している。

ところでリサジュー図形の電荷がゼロの電圧軸を横切る 幅の大きの $1 / 2$ の值が放電ギャップの平均的（マクロ的）な 放電維持電圧 $\mathrm{V}^{*}$ であり ${ }^{(7)(9)}$ ，平均的な換算電界強度 $\mathrm{Td}=$ $\mathrm{V} * / \mathrm{Pd}$ である。著者らは $\mathrm{Td}$ とオゾン収率 $\eta$ max. の関係を求 めた報告をしており ${ }^{(8)}$, 本実験範囲ではギャップ長 $\mathrm{d}$ が小さ くなると $\mathrm{Td}$ は大きくなり，これに伴い $\eta$ max.は増加する。 しかし，実験では電極が清浄な場合と錆が付着した場合の $\mathrm{V}^{*}$ は同じ，すなわちマクロ的に見た平均的な維換算電界強 度 $\mathrm{Td}$ の変化は無いので, 無声放電の放電形成過程や放電中 の電界分布などミクロ的な現象の変化が関係しているのか もしれない。

以上，金属電極の錆は無関係でガラス電極上の錆のみが 原因であることから, 錆の成分が単独でオゾン生成反応に 対して, 触媒的な作用を及ぼしているとは考え難く，錆の 付着による放電状態のミクロ的な恋化が考えられるが，詳 細な検討は課題として残される。

〈3.3〉 オゾン収率向上の条件 図 7 は錆が付着した 場合と清浄な場合のオゾン発生特性の差を広範囲の条件に 渡って調べた結果である。図は先に示した図 3,4 のような放 電電力とオゾン発生量のグラフを, W/ $Q_{N}\left(Q_{N}\right.$; 酸素流量, $\mathrm{L} / \mathrm{min})$ とオゾン濃度 $\mathrm{CO}_{03}$ の関係に再整理して ${ }^{(10)}$, 放電密

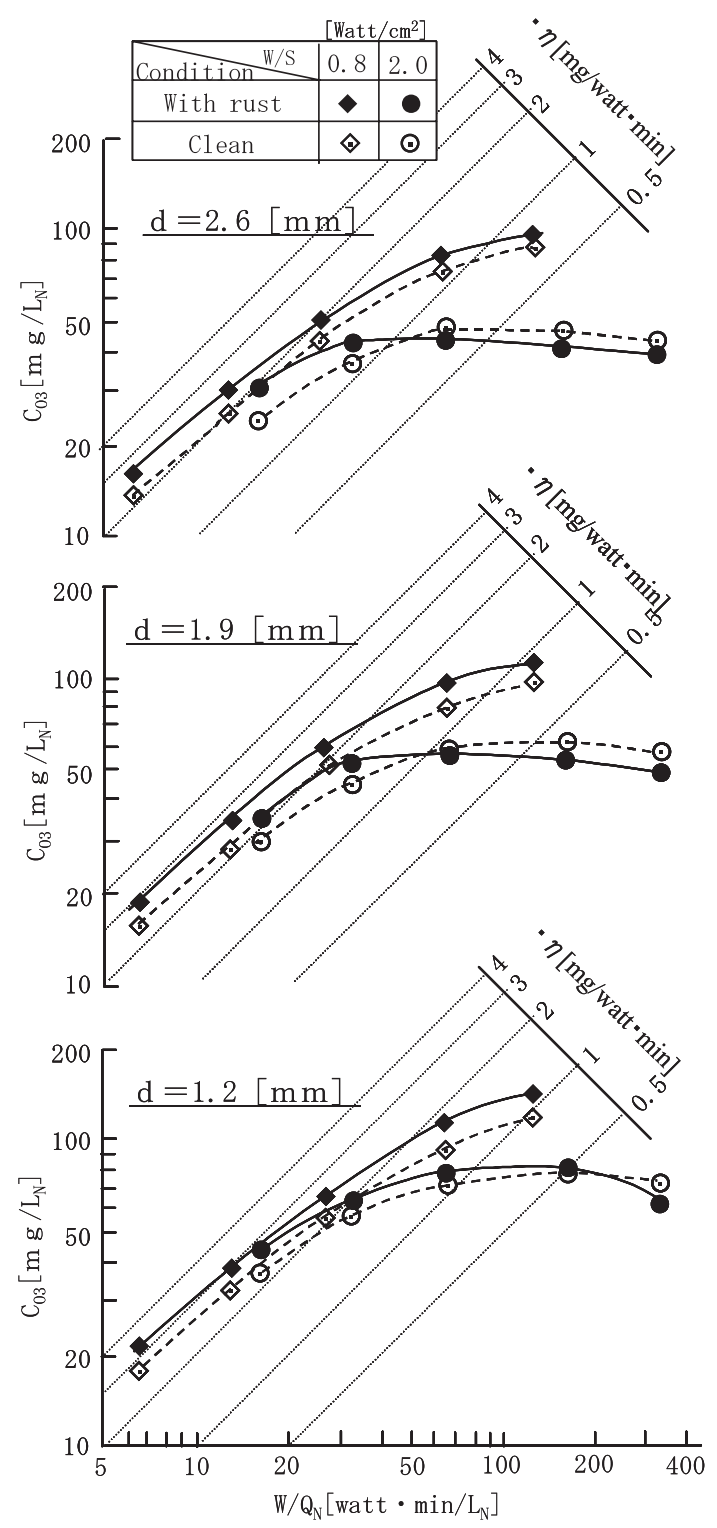

図 7 ギャップ長, 放電密度の影響

Fig. 7. Influence of gap length and discharge density.

度 W/S をパラメータとして示したものである。このグラフ はW/S を一定としたグラフに再整理されているので, 同じ 放電ギャップでは同じ放電空間の温度でのオゾン発生特性 を示している事になりオゾン発生の現象を把握しやすい。 図中にオゾン収率 $\eta \quad\left(\mathrm{C}_{0} \times \mathrm{Q}_{\mathrm{N}} / \mathrm{W}\right)$ の読取線を示す。

図 7 より, W/S が $0.8 \mathrm{watt} / \mathrm{cm}^{2}$ ではd $\mathrm{d} \mathrm{Co}_{3}$ によらず常 に錆が付着した方がオゾン収率は良くなっているが，W/S が 2.0 では，ある $\mathrm{Co} 3$ の值でオゾン収率 $\eta$ は逆転する。こ の逆転する所の $\mathrm{C}_{0}$ の值はギャップ長 $\mathrm{d}$ が小さいほど大き く,また図には詳しくは示していないが W/S が小さいほど 大きくなっている。これらから, 酸素原料オゾナイザでは 錆の付着に関しては，短ギャップにするほど大きな W/S ま でオゾン収率の増加が見込めることになり，この現象を積 極的に取り入れてオゾナイザの設計を行うことでより高効 
率で最適なオゾナイザが実現できる。

次にこの現象を考察する。前述したようにオゾン濃度 Co3 が低い領域，すなわち $\eta$ max. は”放電の状態”のみによっ て決まり，錆が付着すると“放電の状態”がオゾン発生に 好ましい状態になる。一方オゾン濃度が高い領域では，そ れに加えてオゾンの反応空間の温度の影響が出てきて, 温 度が高くなるとオゾン収率 $\eta$ は下がる(2)(8)。

同一ギャップ長で同じ W/S であれば放電空間の平均的な 温度は同じであるが(10)，図 7 が示すように W/S が 2.0 では 錆が付着したほうがオゾン収率は低下する領域もある。こ れは反応空間の温度は高くなっているのと等価の特性を示 していることになり, 放電空間の平均的な温度で無く, 才 ゾンが生成される一本の放電中のミクロな領域での温度が 高くなっている可能性もある。

結局, 先の $\langle 3 \cdot 2\rangle$ 節で示したオゾン濃度の低い領域での $\eta$ max.の現象と同様に，オゾン濃度の高い領域でも錆が付着 したことによる放電のミクロな現象の変化を考える必要が あると思われるが，検討は今後の課題として残される。

〈3.4〉 オゾン発生に影響を与える錆の成分 錆の中に 含まれる何の成分がオゾン発生に影響を与えているのかを 調べるために実験を行った。電極に付着している錆を採取 して, 赤外分光法によって分析した結果, 金属電極（不錆 鋼；SUS304）の成分である $\mathrm{Fe}, \mathrm{Cr}, \mathrm{Ni}, \mathrm{Mo}$ の酸化物の

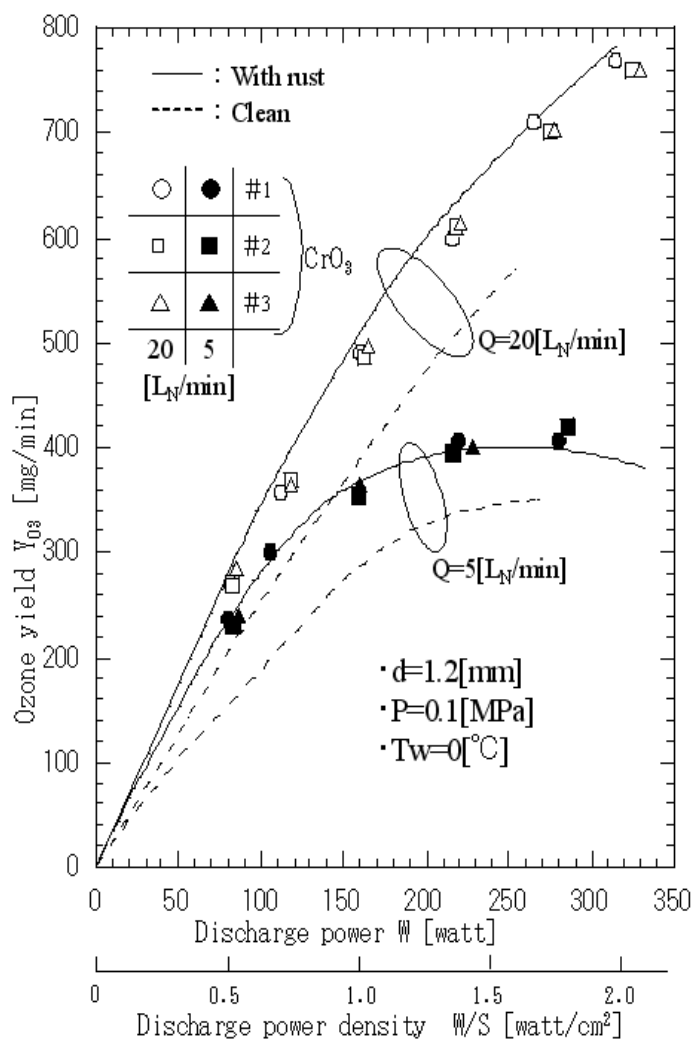

図 $8 \mathrm{CrO}_{3}$ をガラス電極に塗布した場合の オゾン発生特性

Fig. 8. Characteristics of ozone generation using glass electrode of $\mathrm{CrO}_{3}$ painting.
みが検出された。そこでこれらの物質の酸化化合物を純水 で溶いて, 清浄なガラス電極に塗布してオン゙ン発生特性を 調べた (金属電極は清浄)。塗布材料を表 1 に示す。実験に 使用した塗布材料の種類の選定は特に物理的な意味は無く, 不錆鋼の成分の化合物で身近に入手できたものを使用した。

表 1 の材料でギャップ長 $\mathrm{d}=1.2 \mathrm{~mm}$ のオゾナイザを使っ たオゾン発生特性の実験結果をまとめると次のようである。

(ア） $\mathrm{CrO}_{3}$ と $\mathrm{Cr}\left(\mathrm{NO}_{3}\right)_{3}$ を塗布した場合にはオゾン発 生は錆が電極に付着した場合とほぼ同一となった。

（イ） $\left(\mathrm{NH}_{4}\right) \mathrm{MoO}_{4}$ と $\mathrm{Na}_{2} \mathrm{Cr}_{2} \mathrm{O}_{7}$ を塗布した場合には清 浄な場合と錆が付着した場合との中間的な特性にな つた。

（ウ）その他の化合物を塗布した場合は清浄な場合とほ ぼ同じであった。

この中で一例として顕著な効果のあった $\mathrm{CrO}_{3}$ を添付し た場合のオン゙ン発生特性を図 8 に示す。 $\mathrm{CrO}_{3}$ はガラス電極 が淡い黄色になる程度に塗布した。図中の破線のグラフは ガラス電極が清浄な状態, 実線はガラス管に錆が付着した ときの特性であり, 先の図 3 のガス流量 $\mathrm{Q}=20$ および 5 $\mathrm{L}_{N} / \mathrm{min}$ のグラフを抜き出したものである。図中には $\mathrm{CrO}_{3}$ を塗布したときの実験值のプロットのみをのせている。実 験は 3 回行っており, 各々\#1, \#2, \#3 としている。長時 間放電による金属電極からの錆の発生による影響を除くた め, $\mathrm{CrO}_{3}$ 塗布のガラス管挿入後, 1 時間程度放電した後に オゾン発生実験のデータを収得した。図 8 より, $\mathrm{CrO}_{3}$ を塗 布した時のオゾン発生は, 実線で示寸特性に近い值になって おり, $\mathrm{CrO}_{3}$ を塗布することでも放電で錆が付着した場合の オゾン発生とほぼ同等の変化が再現できることが分かった。

尚, これらの実験で上の(ア)の $\mathrm{CrO}_{3}, \mathrm{Cr}\left(\mathrm{NO}_{3}\right)_{3}$ 塗布の場 合のリサジュー図形は先に示した図 6 と同じようにガラス 電極がマイナスの極性の放電期間で動摇が大きくなり, 放 電の様相も錆が付着したときと類似したものになっている

表 1 ガラス電極に塗布した材料

Table 1. Materials painted on glass electrode.

\begin{tabular}{|l|}
\hline $\begin{array}{l}\text { Painting } \\
\text { materials }\end{array}$ \\
\hline $\mathrm{CrO}_{3}$ \\
\hline $\mathrm{Cr}\left(\mathrm{NO}_{3}\right)_{3}$ \\
\hline $\mathrm{Na}_{2} \mathrm{Cr}_{2} \mathrm{O}_{7}$ \\
\hline$\left(\mathrm{NH}_{4}\right) \mathrm{MoO}_{4}$ \\
\hline $\mathrm{Cr}_{2} \mathrm{O}_{3}$ \\
\hline $\mathrm{K}_{2} \mathrm{Cr}_{2} \mathrm{O}_{7}$ \\
\hline $\mathrm{FeO}_{3}$ \\
\hline $\mathrm{Fe}{ }_{3} \mathrm{O}_{3}$ \\
\hline $\mathrm{NiO}$ \\
\hline $\mathrm{Ni}\left(\mathrm{NO}_{3}\right)_{2}$ \\
\hline
\end{tabular}


と推察される。

以上の結果から，金属電極の成分である $\mathrm{Cr}$ やMo の化合 物がオゾン発生に影響を与えている原因の一つであること が明らかになった。

\section{4. むすび}

酸素原料オゾナイザで金属電極から発生する錆がオゾン 発生に与える影響について調べた結果，次のことが明らか になった。

（1） ギャップ長が短いほど，また放電密度が大きいほ ど錆の析出速度は早く, それに伴いオン゙ン発生特性は変化 してゆきやがて一定の值に落ち着く。この変化も金属電極 に発生した錆が飛散してガラス電極に付着することが原因 であり金属電極上の錆は関係していない。

（2）ギャップ長 $\mathrm{d}$, 放電電力密度 W/S が小さいほど, 錆が付着した場合にオゾン収率は向上し, $20 \%$ 近くオゾン収 率が向上する条件も存在する。

(3) $\mathrm{CrO}_{3}$ や $\mathrm{Cr}\left(\mathrm{NO}_{3}\right)_{3}$ をガラス電極に塗布すると, 錆 が電極に付着した場合のオゾン発生とほぼ同一となり，金 属電極から発生する錆の成分である Cr がオゾン発生に最も 関係している。

以上, 酸素原料オゾナイザの実験によるオゾン発生特性 の収得方法に対して一つの知見が得られた。最近では酸素 原料でオゾンの高濃度化, システムの小型化のためオゾナ イザは短ギャップ化, 高放電密度化してきており, 本論文 の知見は実用的にも役立つものと考える。

(平成 17 年 2 月 25 日受付, 平成 17 年 5 月 18 日再受付)

\section{文献}

(1) N. Tabata, M. Tanaka, and S. Yagi:"The Characteristics of Ozone Generation from Oxygen by Silent Discharge Ozonizer", T.IEE Japan, Vol.97-B, No.2, pp.100-106 (1977-2) (in Japanese) 田畑則一・田中正明・八木重典 :「無声放電式オゾナイザの酸素原料 オゾン発生特性」電学論 B , 97, 2, pp.100-106 (1977)

（2）田畑則一・田中正明：「オゾナイザの諸特性」, 静電学誌, Vol.7, No.3, pp.150-158 (1983)

（3）森川 茂・高橋一正・栗田 学:「無声放電によるオゾン収率に対す る放電電極上への金属酸化物の塗布効果」, 日本化学誌, No.6, p.711 (1979)

(4) 近藤芳孝・梶田省吾・後田澄夫:「ハニカム担体を用いたオゾナイザ」, 鹿島学術振興財団研究報告書 (環境浄化および水資源有効利用への 放電・プラズマの利用に関する研究), p.17 (1986)

(5) H. Ishioka, M. Toraguchi, H. Nishii, and C. Yamabe : "High Concentration Ozone Generation by Micro Gap Silent Discharge", T.IEE Japan, Vol.122-A, No.4, pp.378-383 (2002-4) (in Japanese)

石岡久道・虎口 信・西井秀明・山部長兵衛 :「マイクロギャップ無 声放電による高濃度オゾン生成」, 電学論 A, 122, 4, pp.378-383 (2002-4)

(6) K. Ohta, N. Wada, and M. Kuzumoto: "Characteristics of Ozone Generation by Both Electrodes Cooling Ozone Generator", T.IEE Japan, Vol.120-A, No.6, pp.695-700 (2000-6) (in Japanese) 大田幸治・和田 昇・葛本昌樹:「極短ギヤップ両面冷却オゾン発生 器によるオゾン発生特性」, 電学論 A, 120, No.6, pp.695-700 (2000)

(7) M. Tanaka and N. Tabata : "Characteristics of Maintenance Voltage in Silent Discharge", T.IEE Japan, Vol.105-A, No.9, pp.495-502 (1985-9) (in Japanese)

田中正明・田畑則一 : 「無声放電の放電維持電圧の特性」, 電学論 $\mathrm{A}$, 105, 9, pp.495-502 (1985)

(8) M. Tanaka and T. Tamida : "Muximum Ozone Yield Efficiency of Silent Discharge Ozonizer", The Paper of Technical Meeting on Electrical Discharge, IEE Japan, ED-03-152, pp.67-70 (2003) (in Japanese)

田中正明・民田太一郎：「無声放電式オゾナイザの最大オゾン収率」, 電気学会放電研資, ED·03-152, pp.67-70 (2003)

(9) M. Tanaka, T.Tamida, and S.Yagi : "Silent Discharge Characteristics of Ozonizer, CO2 Laser and PDP ”, Xll International Conference on Gas Discharges and their Applications, No.1, pp.311-314 (2000)

（10）田中正明・民田太一郎：「オゾン生成のパラメータ W/Q」第 10 回日 本オゾン協会年次研究講演会講演集, pp.43-46 (2000)

田 中 正明 (正員) 1948 年 8 月 25 日生。 1974 年 3 月同

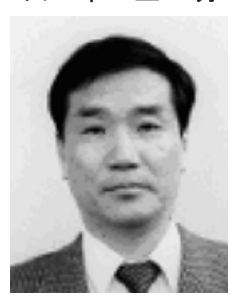
志社大学大学院工学研究科電気工学専攻修士 課程修了。1974 年 4 月三菱電機侏入社。以来, 中央研究所, 応用機器研究所, 生産技術研究所, 先端技術総合研究所で大容量オゾナイサシス テム, イオンビーム薄膜形成装置, 各種大出力 レーザ, プラズマディスプレイ, など主として 放電応用の研究開発および研究企画・管理に従 事。工学博士 (名古屋大学)。放電学会, レーザ学会会員。

小 川 周 治

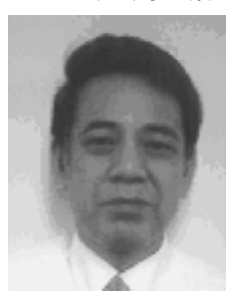

（非会員） 1954 年 09 月 14 日生。1973 年 3 月大阪府立和泉工業高等学校電気科卒業。同年 4 月三菱電機(株)入社, 中央研究所, 応用機器 研究所でオゾン発生装置, 炭酸ガスレーザ発振 器の研究開発に従事。1985 年同名古屋製作所 にて炭酸ガスレーザ加工機の製品化, 設計に従 事。現在, 同中部支社勤務。

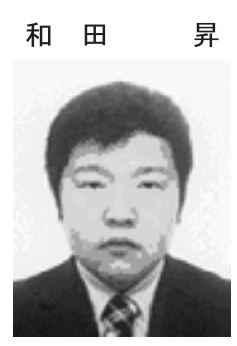

（正員） 1970 年 7 月 23 日生。1994 年名古屋 大学工学部電子工学科卒業。1996 年同大学修 士課程 (電気工学専攻) 修了。同年三菱電機(株) 入社, 先端技術総合研究所にて, 主としてオゾ ン発生技術に関寸る研究に従事。

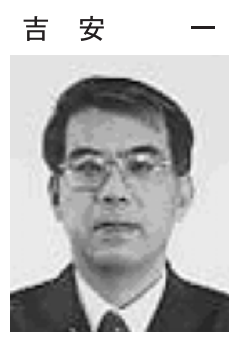

（正員） 1948 年 1 月 22 日生。 1972 年 3 月東 京大学大学院電子工学科修士課程修了。1974 年三菱電機株入社。高圧アーク遮断機, 光デバ イス, 高電圧絶縁材料, リチュウムイオンポリ マ一二次電池, 瞬低補償装置, 固体高分子型燃 料電池の開発に従事。現在, 先端技術総合研究 所技師長。工学博士 (東京大学)。

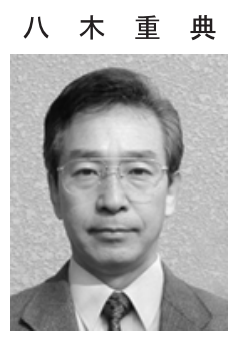

（正員） 1972 年, 東京大学大学院電気工学修 士課程修了。1972 年三菱電機 (株) 入社, 中 央研究所を経て応用機器研究所, 先端技術総合 研究所で放電応用機器, 高出力レーザの開発に 従事。工学博士 (東京大学)。現在, 開発本部 役員技監, レーザ学会理事。 